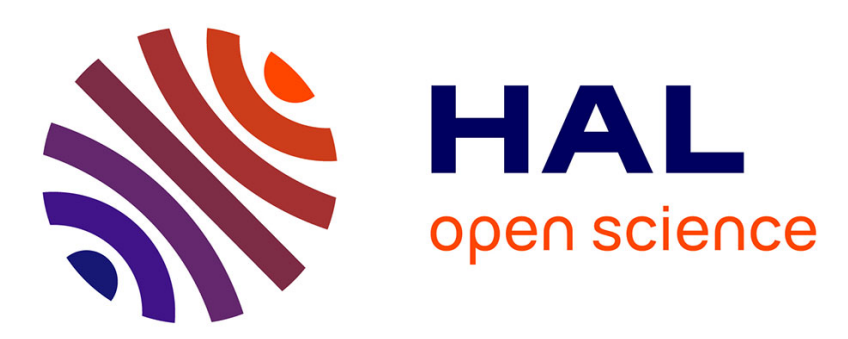

\title{
APPLICATION OF SATELLITE REMOTE SENSING TO ESTIMATE AREAL EVAPOTRANSPIRATION OVER A WATERSHED
}

\author{
Y Sucksdorff, C Ottle
}

\section{> To cite this version:}

Y Sucksdorff, C Ottle. APPLICATION OF SATELLITE REMOTE SENSING TO ESTIMATE AREAL EVAPOTRANSPIRATION OVER A WATERSHED. Journal of Hydrology, 1990, 121, pp.321-333. hal-03299109

\section{HAL Id: hal-03299109 \\ https://hal.science/hal-03299109}

Submitted on 27 Jul 2021

HAL is a multi-disciplinary open access archive for the deposit and dissemination of scientific research documents, whether they are published or not. The documents may come from teaching and research institutions in France or abroad, or from public or private research centers.
L'archive ouverte pluridisciplinaire HAL, est destinée au dépôt et à la diffusion de documents scientifiques de niveau recherche, publiés ou non, émanant des établissements d'enseignement et de recherche français ou étrangers, des laboratoires publics ou privés. 


\title{
APPLICATION OF SATELLITE REMOTE SENSING TO ESTIMATE AREAL EVAPOTRANSPIRATION OVER A WATERSHED
}

\author{
Y. SUCKSDORFF ${ }^{1}$ and C. OTTLE ${ }^{2}$ \\ ${ }^{1}$ National Board of Waters and the Environment, BP 250, 00101 Helsinki (Finland) \\ ${ }^{2} \mathrm{CNET/CRPE-CNRS,38/40}$ rue du Général Leclerc, 92131 Issy-les-Moulineaux (France)
}

(Received November 15, 1989; accepted after revision March 22, 1990)

\begin{abstract}
Sucksdorff, Y. and Ottle, C., 1990. Application of satellite remote sensing to estimate areal evapotranspiration over a watershed. J. Hydrol., 121: 321-333.

A method for estimating areal evapotranspiration by using synoptical weather data and satellite imagery is presented. Recent studies have shown that if atmospheric and surface parameters are known, the energy and hydraulic budgets at the soil/vegetation/atmosphere interface can be simulated. Then, soil temperature estimated by thermal infrared remote sensing can be used to derive the energy fluxes as far as they are the equilibrium term of the energy budget. This methodology has been applied in southwestern Finland over the Eurajoki River basin. The model was first calibrated with ground measurements and satellite data. The NDVI and the surface temperature estimated from NOAA/AVHRR data have been used to calibrate the leaf area index and the minimum resistance to evapotranspiration. The different land use classes over the river basin were interpreted from LANDSAT/TM images, and the model was then run over the whole month of July 1988 for all the most important soil and vegetation types of the river basin. Finally, the total derived evaporation was compared with the one estimated by a water balance method applied over the month of July.
\end{abstract}

\section{INTRODUCTION}

Soil moisture and evapotranspiration have been shown to correlate highly with radiometric surface temperature through the energy balance at the landatmosphere interface. In recent years, many studies have shown that by combining thermal infrared remote sensing, in situ measurements of surface and atmospheric parameters, and modeling of surface energy fluxes, soil moisture and evapotranspiration can be estimated.

The procedure entails the use of a one-dimensional interface layer model in conjunction with surface temperatures estimated from thermal infrared measurements to obtain the energy fluxes and one or two soil or vegetation parameters. For example, Carlson et al. (1981) and Soarès et al. (1988) have shown that over bare soils (over a 10-day period), thermal inertia, hydraulic diffusivity or soil water content in the first $(5-10 \mathrm{~cm})$ soil surface layer can be estimated providing that the other soil parameters and the atmospheric demand are known. In the presence of vegetation the exchanges are more 
complex, though soil parameters are less influential. The interface temperature, however, is closely related to the available water in the root zone. When the soil water is restricted, the plant reduces its transpiration and the system temperature rises. The radiometric surface temperature measurements may then be used to monitor the soil water budget and evapotranspiration during the growing periods for crops, for example for irrigation purposes.

Much work has been done to model the exchanges between soil/vegetation and atmosphere. Over a flat homogeneous and fully covered agricultural region in France, using an algorithm based on the formalism of Deardorff (1978) and simplified by Bernard et al. (1986), Taconet et al. (1986) showed that one single early afternoon temperature, which can be derived from NOAA/VHRR satellites for example, is sufficient to infer surface fluxes and then global canopy resistance to evaporation on a regional scale.

The algorithm has been tested using images from NOAA/AVHRR over a period of five consecutive days during which, estimated soil water content and atmospheric fluxes have been compared with ground measurements at the same scale as the satellite data. The methodology used either by Taconet et al. (1986) for vegetated areas or by Soarès et al. (1988) for bare soils has then been tested over very short periods to validate the soil/vegetation/atmosphere interaction model. The aim of this paper is to show that the methodology may be used to monitor watershed water budgets over periods longer than one week and that satellite remote sensing is a good tool to calibrate and reinitialize a regional water budget. This is done here over the Eurajoki River basin in southwestern Finland. The model is first calibrated for this particular area using existing ground and satellite measurements or equivalent literature data. The surface temperature estimated from thermal infrared brightness temperature (AVHRR, Channel 4) has been used to fix the minimum resistance to evaporation, and the normalized difference vegetation index (AVHRR, Channels 1 and 2) helped to calibrate the vegetal covering and the canopy roughness. The model is then run over the entire month of July 1988 during which NOAA/AVHRR satellite data were available for two different days. Finally, the calculated cumulative evaporation over the watershed calculated by our methodology is compared with the same parameter estimated by a water balance method.

AREA, MODEL AND DATA DESCRIPTION

\section{The area under study}

This study was made in the Eurajoki River basin and its two sub-basins situated in southwestern Finland, as presented in Fig. 1. This region has been chosen because hydrological and land use data were available. These three basins are mostly covered by forests $(\sim 50 \%)$ and agricultural areas $(\sim 30 \%)$. The lake area varies between 0 and $25 \%$, as shown in Table 1 . The soil types of different land use classes were interpreted from geological maps. In the agricultural areas the soil is mostly heavy clay with a grain size smaller than 

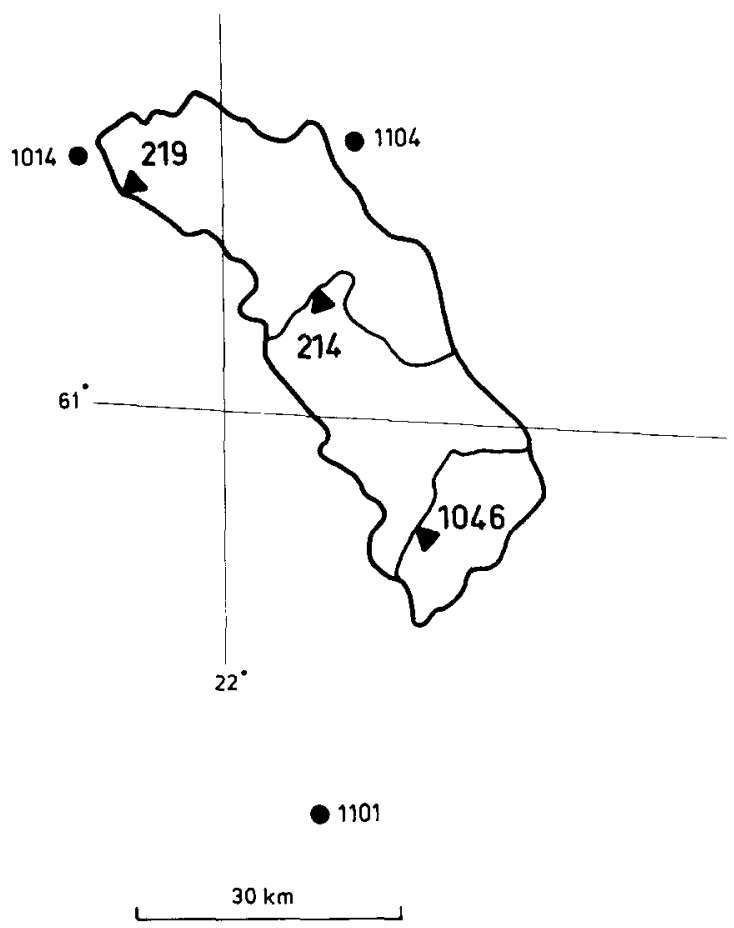

Fig. 1. The area under study, the Eurajoki River basin and its two sub-basins, the synoptical stations (1101, 1104 and 1014) and the Jokioinen observatory (1201) where the incident solar radiation and the atmospheric soundings were measured.

$0.002 \mathrm{~mm}$, which is typical of southwestern Finland. In the other open areas, the soil is generally sand. In the forested areas it is mostly till, sand and peat. Outcrops of bedrock are also common in some parts of the area.

\section{The model}

The soil/vegetation/atmosphere model used in this study has already been

\section{TABLE 1}

Characteristics of the Eurajoki River basin (219) and its two sub-basins (214 and 1046)

\begin{tabular}{|c|c|c|c|c|c|}
\hline \multirow{2}{*}{$\begin{array}{l}\text { Basin } \\
\text { No. }\end{array}$} & \multirow{2}{*}{$\begin{array}{l}\text { Area } \\
\mathrm{km}^{2}\end{array}$} & \multicolumn{4}{|c|}{ Percentage of } \\
\hline & & water & $\begin{array}{l}\text { agricultural } \\
\text { land }\end{array}$ & $\begin{array}{l}\text { other open } \\
\text { land }\end{array}$ & forest \\
\hline 219 & 1225.0 & 14 & 28 & 4 & 54 \\
\hline 214 & 616.4 & 25 & 20 & 3 & 52 \\
\hline 1046 & 196.9 & 0 & 33 & 3 & 64 \\
\hline
\end{tabular}


described by Taconet et al. (1986). It follows the formalism of Deardorff (1978) and simultaneously solves the energy budget equations at ground level and canopy level. The vegetation is represented by one layer only, which shields the ground more or less completely depending on a shielding factor $S f$.

To run the model, the daily variation of the atmospheric forcing and the physical and biological behavior of the surface must be known, particularly the plant stomatal resistance. The precipitation has been included because we wanted to run the model over rainy periods. The rain interception is modeled very roughly, because no measurements were available in this study. It is assumed then that it depends only on the shielding factor of the vegetation, so that the maximum amount of intercepted water is given directly by $S f$. No corrections for wind speed, leaf shape, vegetation type, etc. are made. From the precipitation the throughfall is given by $1-S f$. The remaining part of the precipitation is intercepted until a maximum value is reached. The evaporation from the leaves is supposed to be potential. The water which reaches the soil surface infiltrates first to the $10-\mathrm{cm}$ surface layer and after this layer is saturated, to the 10-120-cm layer.

Satellite data are used to determine the shielding factor and the surface temperature. As far as the temperature is controlled by the atmospheric demand and the daily minimum stomatal resistance, this last parameter can be estimated when a satellite image is available by comparing the model simulated surface temperature with the satellite data. As we wanted to model the surface fluxes over a large and non-homogeneous area, the model was calibrated and run over the most important soil and vegetation types in the river basins.

\section{The meteorological data}

The daily prescription of the atmospheric forcing is necessary to run the model. The atmospheric parameters needed are: windspeed, air temperature and humidity at standard levels, incoming solar radiation and precipitation.

To obtain the atmospheric forcing over the entire river basin, the data of three stations (1101, 1014 and 1104, see Fig. 1) have been averaged. Windspeed, air humidity and air temperature were measured for station 1101 every $3 \mathrm{~h}$ but for the other two stations every $6 \mathrm{~h}$, except for the humidity and moisture, which were not measured at midnight. These values were interpolated by means of the data from station 1101, supposing that the mean trend of change of the moisture or the wind speed between 18:00 $\mathrm{h}$ and $24: 00 \mathrm{~h}$ and 24:00-06:00 h is the same at stations 1014 and 1104 as at station 1101. After the midnight values have been calculated, values for every hour have been interpolated linearly, and finally the arithmetic means of the values for the three stations were calculated. The incoming shortwave radiation hourly data were taken from the Jokioinen observatory 1201. The precipitation was measured only once a day in the three synoptical stations around the Eurajoki River basin, but twice a day at Jokioinen. A weighted mean for the areal precipitation was 
calculated by Thiessen's method. A correction factor of 1.08, which is a typical value for July in southern Finland, was used. Daily values from class-A pan evaporation were also available at Jokioinen and have been used for comparison with the monthly models.

\section{CALIBRATION OF SURFACE PARAMETERS}

Previous studies have indicated the importance of soil and vegetation parameters on the fluxes simulated by the model. Soarès et al. (1988) have shown that over bare soils the model is most sensitive to three parameters. These are: heat conductivity, hydraulic diffusivity and 'limiting evaporation', which is defined as the maximum upward water flux within the soil and which can be estimated knowing the soil hydraulic properties. Over dense vegetated areas, the sensible parameters are: leaf area index $(L A I)$, height of vegetation $(h)$ and minimum resistance to transpiration $\left(R_{0}\right)$ (Taconet et al., 1986). For partially covered areas it is then necessary to determine all these parameters. To do so, all available surface data have been used and we show in the following sections how these parameters were determined.

\section{Calibration for vegetation parameters}

The leaf area index $L A I$ (which in the model determines the shielding factor), $h$ and $R_{0}$ have been estimated from land-use maps and satellite data.

For the determination of the land-use parameters, LANDSAT/TM images and the digitized map data have been used (Kuittinen and Sucksdorff, 1987). The image processing for the land-use was done at the National Board of Survey in Finland. Digitized bog data were also used to improve the bog/forest classification. The total number of classes interpreted was about 50 , the main classes being water areas, agricultural fields, clear cuttings, open bogs, forested bogs and forests. The classes include information about the forest or bog types and about the volume of growing stock. For the model calculations presented in this paper, the classes were combined into four: water areas, agricultural fields, other open areas and forests. The interpreted LANDSAT/ TM images were combined with digitized drainage basins with a GIS-program called FINGIS (FINnish Geographic Information System) to calculate the area of different land-use classes inside the river basins. These areas were then used for monthly areal evaporation calculations after the evapotranspiration from different land-use type was calculated using the model.

In order to follow vegetation parameters from space, it is necessary to have a good repetition and as fine a resolution as possible. The data from NOAA/ AVHRR were then chosen. The NOAA images were acquired by the French Spatial Meteorological Office from Tromsö, Norway. Only three daytime images of June 17, July 6 and July 14, 1988 could be used in this study. All these images are partly cloudy, especially the last one. The images were rectified and calibrated after they were preprocessed at the French Meteorological Office. 
TABLE 2

$N D V I$ and surface temperatures $\left(T_{\mathrm{s}}\right)$ averaged over all the homogeneous agricultural areas in the Eurajoki River basin and their standard deviations $(\sigma)$ calculated from NOAA/AVHRR images. $n$ is the number of pixels in the calculations, $T_{\mathrm{m}}$ is the modeled surface temperature

\begin{tabular}{lllllll}
\hline Date & $\begin{array}{l}\text { NDVI } \\
(\%)\end{array}$ & $\begin{array}{l}\sigma \\
(\%)\end{array}$ & $\begin{array}{l}T_{\mathrm{s}} \\
\left({ }^{\circ} \mathrm{C}\right)\end{array}$ & $\begin{array}{l}\sigma \\
(\%)\end{array}$ & $n$ & $\begin{array}{l}T_{\mathrm{m}} \\
\left({ }^{\circ} \mathrm{C}\right)\end{array}$ \\
\hline June 17 1988 & 56.6 & 2.1 & 26.1 & 1.2 & 45 & \\
July 6 1988 & 56.3 & 1.7 & 27.3 & 0.5 & 36 & 26.1 \\
July 14 1988 & 53.5 & 2.1 & 27.3 & 2.8 & 18 & 26.7 \\
\hline
\end{tabular}

The images were navigated by means of a rectified LANDSAT/MSS image with a spatial resolution of $100 \mathrm{~m}$.

The $L A I$ was estimated from normalized difference vegetation indexes (NDVI) calculated using visible and near infrared measurements from NOAA9/AVHRR. The NDVI values were corrected for gaseous absorption (water vapor and ozone), and Rayleigh scattering by the method given in Phulpin et al. (1989), and were found to be approximately constant for the three images, as shown in Table 2. For this reason, the deduced $L A I$ value of 4 and a value of $h$ of $1 \mathrm{~m}$ were assumed to represent the mean values for the Eurajoki River basin in July 1988.

The shielding factor is another sensible parameter of our model because it determines the energy partition between the vegetation and the soil. It is calculated by the following equation:

$S f=1-\exp (-L A I \cdot \mathrm{C})$

where $\mathrm{C}$ is a constant, and has been assigned a value of $0.4(S f=0.8)$ from Taconet et al. (1986). The albedo of the vegetation has been fixed at 0.2 in accordance with the measurements made by Solantie (1988).

The surface temperature measured by the satellite has been used to estimate $R_{0}$, the minimum resistance to transpiration (Deardorff, 1978):

$R S T=R_{0} \frac{P S}{L A I}\left[\left(\frac{S_{\max }}{1+S_{\mathrm{i}}}\right)+\left(\frac{1.2 W_{\text {wilt }}}{0.9 W_{2}+0.1 W_{\mathrm{g}}}\right)^{2}\right]$

where: $R S T$ is the foliage resistance to transpiration, $S_{\mathrm{i}}$ is the incident solar flux; $S_{\max }$ is the maximum noon incoming solar radiation which can be provided; $W_{\text {wilt }}$ is the wilting point; $W_{2}$ and $W_{\mathrm{g}}$ are the soil moisture values in the root zone $(1.20 \mathrm{~m})$ and in the top $10 \mathrm{~cm}$ surface layer, respectively; $R_{0}$ is the minimum daily resistance, which includes the seasonal dependence on the physiology of the vegetation; $P s$ is an empirical factor which is a function of LAI.

The surface infrared temperature was determined from the three NOAA/ AVHRR images from the water vapor atmospheric window (thermal infrared, $10.5-11.3 \mathrm{~mm}$ ). The data were corrected for atmospheric attenuation with a 


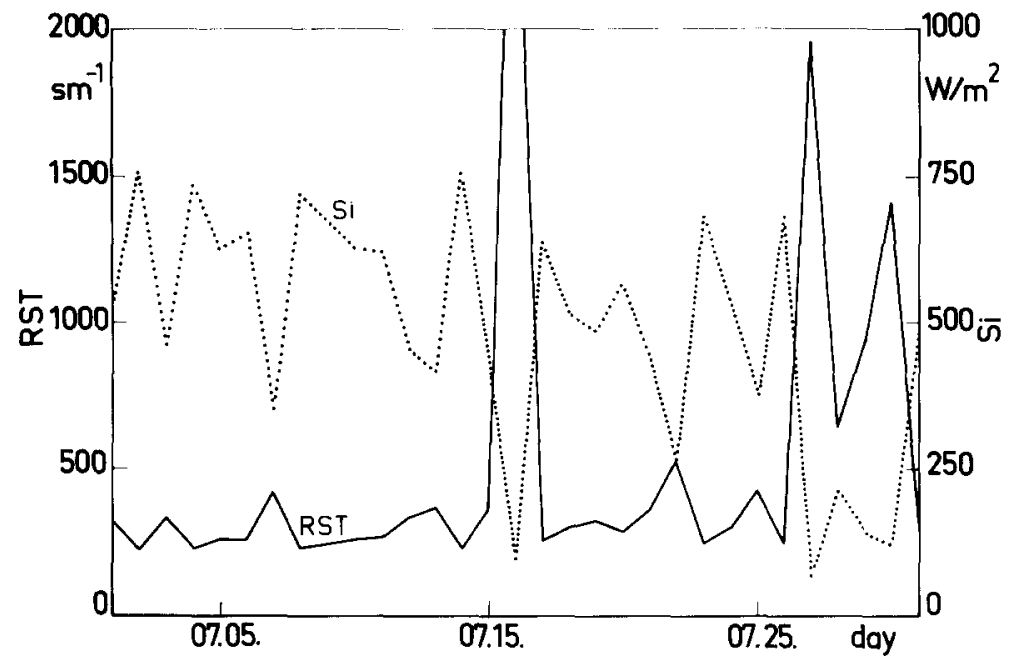

Fig. 2. The modeled midday stomatal resistance $R S T$ compared with the measured midday solar radiation $S_{\mathrm{i}}$ for July 1988 .

radiative transfer model LOWTRAN6 (Kneizys et al., 1983), which uses atmospheric vertical profiles, pressure, temperature and humidity given by radiosounding as input.

For the product $\left(R_{0} \cdot P s\right)$, a constant value of $600 \mathrm{~s} \mathrm{~m}^{-1}$ has been found to reduce the differences between the satellite infrared temperatures and the modeled surface temperatures (see Table 2). The differences were equal to $1.2^{\circ} \mathrm{C}$ on July 6 and $0.6^{\circ} \mathrm{C}$ on July 14 , which can be considered satisfactory. The daily midday $R S T$ and $S_{\mathrm{i}}$ are shown in Fig. 2. The midday $R S T$ is very dependent on the incident solar radiation when $L A I, R_{0}$ and $P S$ are kept constant.

\section{Calibration of soil parameters}

Soil measurements were made on only two sites, one over a clay soil and the other on a sandy soil in the Eurajoki River basin.

\section{Hydraulic parameters}

For the hydraulic diffusivity and limiting evaporation calculations, three different soil classifications have been tested: $\mathrm{C}_{1}$ (Zobler, in Abramopoulos et al., 1988), $\mathrm{C}_{2}$ (Clapp and Hornberger, 1978), and $\mathrm{C}_{3}$ (Cosby et al., 1984).

For small moisture values, there is practically no difference between the three classifications in the hydraulic diffusivity values. The difference becomes insignificant when the volumetric moisture is less than $65 \%, 25 \%$ and $35 \%$ of the maximum moisture for clay, sand and loam, respectively. At high water content, the difference is more important and can affect the moisture movement between the surface and the deeper layer. 


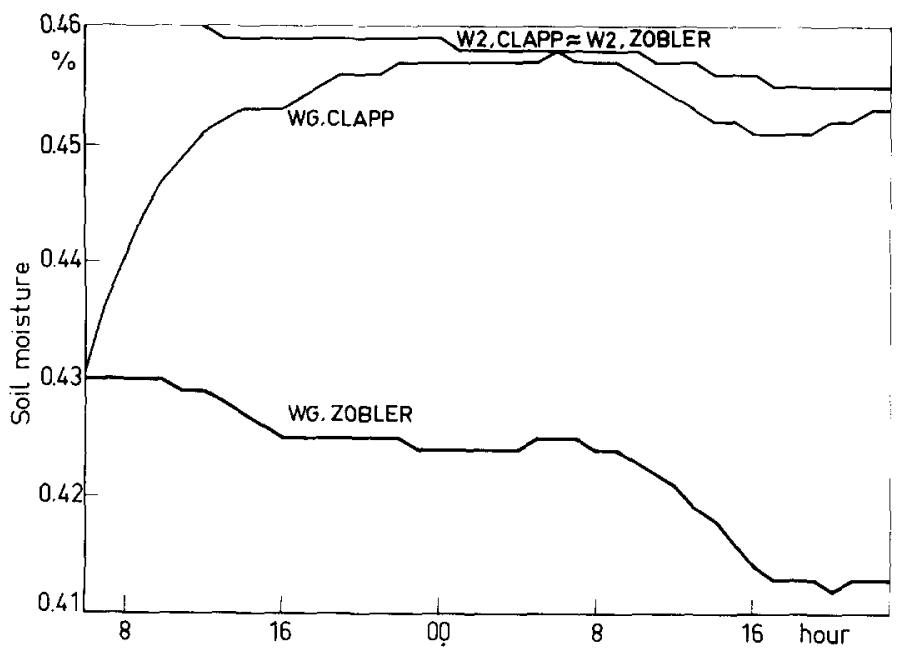

Fig. 3. Modeled moisture values in the $10 \mathrm{-cm}$ surface layer $\left(W_{\mathrm{g}}\right)$ and in the $120-\mathrm{cm}$ root zone $\left(W_{2}\right)$ for $41 \mathrm{~h}$ for two different soil parameterizations: $\mathrm{C}_{1}$ (after Zobler) and $\mathrm{C}_{2}$ (after Clapp and Hornberger) for a non-rainy period.

Figure 3 shows the modeled moisture changes in the $0-10-\mathrm{cm}$ and $0-120-\mathrm{cm}$ layers with two different parameterizations during 2 days of July: With $\mathrm{C}_{2}$ classification, the surface moisture rises too fast close to the $120-\mathrm{cm}$ layer, because the water uptake exceeds the surface evapotranspiration. With $\mathrm{C}_{1}$, the upward water flow is much slower, thereby letting the surface layer dry during the daytime. The soil surface limitation to evaporation $E_{\mathrm{lim}}$ is derived from the equations for soil water movement. It is calculated from the hydraulic conductivity profile using the following integration (Soarès et al., 1988):

$E_{\lim }=\int_{\theta_{\mathrm{r}}}^{\theta\left(z_{0}\right)} D(\theta) \mathrm{d} \theta$

assuming a constant flux profile between $z=0$ and some reference level $z_{0}$, where $D$ is the water diffusivity and $\theta_{\mathrm{r}}$ is the residual soil moisture when the water pressure head tends to become infinite.

The choice of a particular soil classification will have an influence on the calculated evapotranspiration for partial vegetation canopy. This is the case even for a $L A I$ as high as 4 . During the month of July 1988 (for which $L A I$ has been set equal to 4 ), the monthly cumulative soil surface evaporation varied from $24.6 \mathrm{~mm}$ with $\mathrm{C}_{1}$ to $15.1 \mathrm{~mm}$ with $\mathrm{C}_{3}$. The difference may reach $10 \%$. This is owing to the different values simulated for the surface soil moisture by the two classifications as shown in Fig. 3.

Finally, the parameterization chosen for the monthly model calculations was $\mathrm{C}_{1}$ (Zobler, in Abramopoulos et al., 1988) mainly because of its more realistic values for hydraulic diffusivity. 
For the initialization of the model, soil moisture values for the superficial layer $W_{\mathrm{g}}(0-10 \mathrm{~cm})$ and the root zone $W_{2}(0-120-\mathrm{cm})$ were needed and were obtained with a neutron probe. Unfortunately, very few of the measured soil moisture values could be used. At the sandy site, the soil moisture was measured only twice, on May 13 and July 29, 1988 in the southeastern part of the Eurajoki River basin. $W_{\mathrm{g}}$ changed from 0.14 to $0.19 \mathrm{~m}^{3} \mathrm{~m}^{-3}$ and $W_{2}$ from 0.10 to $0.12 \mathrm{~m}^{3} \mathrm{~m}^{-3}$ between these two dates. Therefore, the initial soil moisture for July 1 was chosen so that the measured and modeled soil moisture values became the same on July 29. On the clay site, the soil moisture was measured on June 29 and July 5 near the station 1201 . Between these two dates, $W_{\mathrm{g}}$ changed from 0.32 to $0.34 \mathrm{~m}^{3} \mathrm{~m}^{-3}$ and $W_{2}$ from 0.46 to $0.47 \mathrm{~m}^{3} \mathrm{~m}^{-3}$. Porosity was also measured at the two sites, and values obtained were $0.61 \mathrm{~m}^{3} \mathrm{~m}^{-3}$ for clay and $0.34 \mathrm{~m}^{3} \mathrm{~m}^{-3}$ for sand.

\section{Soil heat conductivity}

The soil heat conductivity was measured at the Jokioinen observatory at two different moisture contents. These measurements have been fitted to an equation:

$\lambda=\mathrm{a}+\mathrm{b} W^{1 / 2}$

where $\lambda$ is the heat conductivity $\left(\mathrm{W} \mathrm{m}^{-1}{ }^{\circ} \mathrm{C}^{-1}\right), W$ is the soil moisture $\left(\mathrm{m}^{3} \mathrm{~m}^{-3}\right)$ and $\mathrm{a}$ and $\mathrm{b}$ are constants. For clay in Jokioinen, we obtained the values $a=0.139$ and $b=1.389$. As no measurements were available for sandy soils, the data collected during the HAPEX/MOBILHY (Hydrologic Atmospheric Pilot Experiment/Modèlization du Bilan Hydrique) were used (André et al., 1988). The same equation has been used with values $a=0.082$ and $b=0.768$ (Benmehrez et al., 1990). The initial mean soil temperature in the 0-120-cm layer was set at $290 \mathrm{~K}$ for both soils as measured at Jokioinen. The monthly mean ground heat flux was calculated from the daily soil temperature measurements at depths of 20 and $50 \mathrm{~cm}$. The measured value $\left(2.4 \mathrm{~W} \mathrm{~m}^{-2}\right)$ fitted very well with the modeled monthly mean value $\left(2.6 \mathrm{~W} \mathrm{~m}^{-2}\right)$.

\section{RESULTS OF THE MONTHLY MODELING}

The model has been run for the two main soil types (clay and sand) for open area in the Eurajoki River basin for July 1988.

The meteorological data were used as explained above except for precipitation, as only daily values were available, the effect of the duration of the precipitation on the modeled evapotranspiration was first analyzed. Two different inputs for the precipitation were used: (a) the precipitation was given twice a day as measured; (b) it was supposed that it had fallen with constant intensity during the previous $12 \mathrm{~h}$. The difference in monthly cumulative evapotranspiration between these two methods for July 1988 for Jokioinen was $11 \mathrm{~mm}$, which is about $12 \%$ of the total evaporation. A more realistic combination of these two methods was chosen where the precipitation was assumed to have occurred between 1 and $24 \mathrm{~h}$, depending on the cloud type coded in 


\section{TABLE 3}

Results of monthly areal evaporation calculations for the Eurajoki River basin and its two sub-basins

\begin{tabular}{llllllll}
\hline $\begin{array}{l}\text { Basin } \\
\text { No. }\end{array}$ & \multicolumn{7}{l}{ Evaporation or evapotranspiration $(\mathrm{mm})$} \\
\cline { 2 - 8 } & $W B$ & Cl-A & $E P$ & $E_{\text {sand }}$ & $E_{\text {loam }}$ & $E_{\text {clay }}$ & $E_{\text {tot }}$ \\
\hline 1046 & 118 & 150 & 131 & 96.0 & 88.8 & 96.6 & 119 \\
214 & 120 & 150 & 131 & 96.0 & 88.8 & 96.6 & 121 \\
219 & 121 & 150 & 131 & 96.0 & 88.8 & 96.6 & 118 \\
\hline
\end{tabular}

$W B$, evapotranspiration with water balance method; Cl-A, pan evaporation; $E P$, potential evaporation, $E_{\text {sand }}, E_{\text {loam }}$ and $E_{\text {clay }}$ are modeled evapotranspirations and $E_{\text {tot }}$ is the total modeled evapotranspiration from the corresponding river basin.

Jokioinen, incoming solar radiation in Jokioinen and the amount of the precipitation.

The modeled cumulative evapotranspiration values for open area in the Eurajoki River basin for July 1988 were almost the same for clay and sand, 96.6 and $96.0 \mathrm{~mm}$ respectively (Table 3 ). The modeled daily evapotranspiration was normally much smaller than the daily potential evaporation calculated with Penman's formula or the class-A pan evaporation measured at Jokioinen as can be seen from Fig. 4. In rainy periods, the opposite situation prevails because evapotranspiration calculated by the model is mostly potential evaporation of the intercepted water plus potential evaporation from the ground surface. An

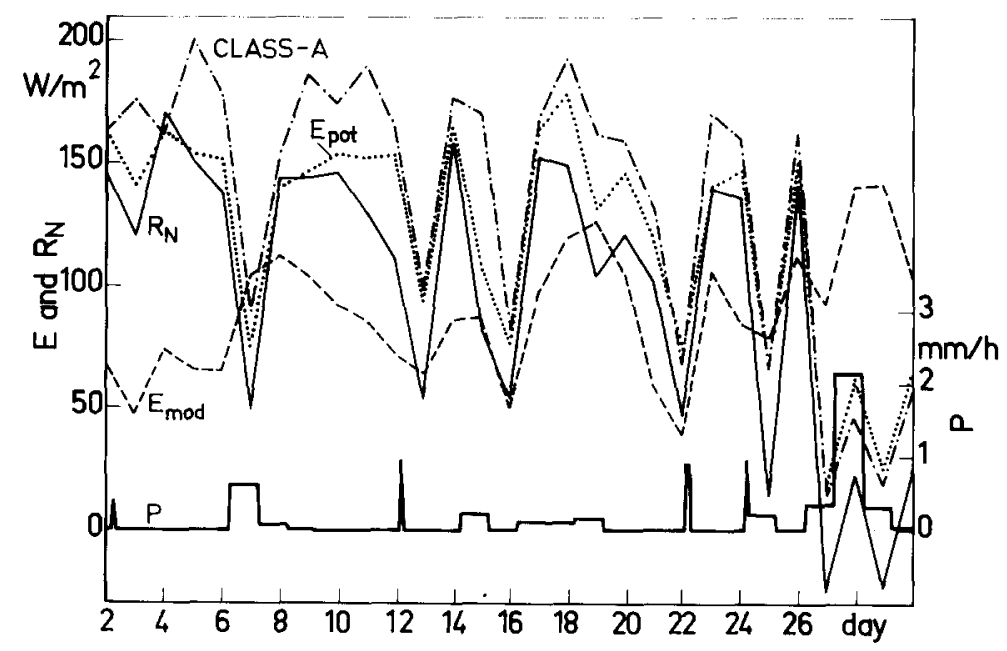

Fig. 4. Daily values of the modeled evapotranspiration $\left(E_{\text {mod }}\right)$, modeled net radiation $\left(R_{\mathrm{n}}\right)$, potential evaporation ( $E_{\text {pot }}$ ), pan evaporation (Class-A) and the measured precipitation $(P)$ for clay soil for the month of July 1988. 


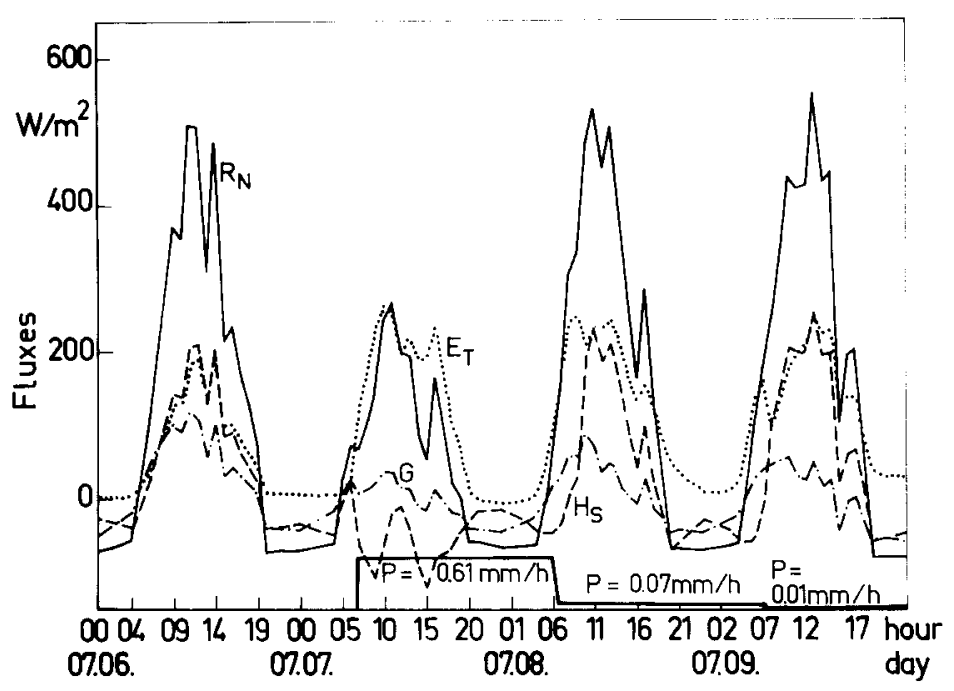

Fig. 5. Modeled hourly fluxes and the measured precipitation $P$ for clay soil for $6-10 \mathrm{July} 1988 . R_{\mathrm{n}}$, net radiation; $E T$, evapotranspiration; $H_{s}$, sensible heat flux and $G$, ground heat flux.

example of the daily fluxes for the period of 6.7 to 10.7 is shown on Fig. 5 , where the effect of the precipitation on the fluxes is also visible.

\section{MODEL COMPARISONS WITH THE WATER BALANCE METHOD}

The areal evapotranspiration for July 1988 has been calculated by the water balance method for the three river basins shown in Fig. 1. The daily mean discharge was measured at the outlets of the basins. The water level was measured daily in the two largest lakes in the area, representing $97 \%$ of the water area for basin 219 and $99 \%$ for basin 214 . Basin 1046 is lakeless. The change in the water storage in the lakes can therefore be taken into account. In the absence of data, the change in soil water storage has been taken as zero. Standard pentad areal precipitation values produced by the Hydrological Office in Finland have been used to evaluate the water input. It has been assumed that the soil in the agricultural area is clay and that it is sand in other open areas. The forest evapotranspiration has been taken as potential. The total areal evapotranspiration for the three river basins presented in Table 1 was then calculated as a weighted mean of evapotranspiration from different soil types. The results in Table 2 showed that the differences between the two methods are very small for the three basins.

\section{CONCLUSIONS}

In this study, we have used satellite visible and infrared remote sensing to calibrate a soil/vegetation/atmosphere model in order to simulate the water budget of a Finnish watershed, during the month of July 1988. The monthly cumulative evapotranspiration values calculated by the model compare very 
well with the same parameter deduced from the water balance method. Although the results have no statistical meaning, the agreement between the two methods may be considered as an indication of the potential of the methodology. The same validation of the simulated evapotranspiration must now be done over longer time periods, to test the accuracy of the model. For this, the seasonal evolution of vegetation and soil parameters must be known precisely, and more field and satellite data are needed. Similar work which has already been undertaken is the HAPEX-MOBILHY experiment being carried out over a period of two years, using an hydrological model in conjunction with NOAA9/AVHRR data (about one image per week), to follow the water budget on decade time periods (Ottlé et al., 1989).

These studies are examples of the use of satellite remote sensing for soil water budget monitoring. Because of its high repetition and spatial resolution, satellite remote sensing is certainly the only way to obtain surface parameters regularly on a scale compatible with the grid of hydrological models, and thus can greatly improve the estimation of soil water budgets at regional scale.

\section{ACKNOWLEDGMENTS}

This work was done at C.R.P.E. and was supported by the Academy of Finland. The NOAA images were acquired by the French Spatial Meteorological Office. A.D. Ho and J.Y. Lojou at C.R.P.E. made it possible to process the images. The LANDSAT images were processed at the National Board of Survey in Finland by the remote sensing and FINGIS groups. M. Benmehrez, R. Bernard, O. Taconet, D. Vidal-Madjar and A. Weill at C.R.P.E. provided much useful advice, and S. Tattari from the National Board of Waters and the Environment in Finland helped in obtaining data. The authors would like to thank all of them.

\section{REFERENCES}

Abramopoulos, F., Rosenzweig, C. and Choudhury, B., 1988. Improved ground hydrology calculations for global climate models (GCM) : Soil water movement and evapotranspiration. J. Clim. Appl. Meteorol., 1: 921-941.

André, J.C. and co-workers, 1988. Evaporation over land surfaces : First results from HAPEXMOBILHY special observing period. Ann. Geophys., 6(5): 477-492.

Benmehrez, M., Taconet, O., Vidal-Madjar, D. and Sucksdorff, Y., 1990. Calibration of a fluxes model over bare soils during HAPEX-MOBILHY experiment. Agric. For. Meteorol., submitted.

Bernard, R., Soarès, J.V. and Vidal-Madjar, D., 1986. Differential bare field drainage properties from airborne microwave observation. Water Resourc. Res., 22(6): 869-875.

Carison, T.N., Dodd, J.K., Benjamin, S.G. and Cooper, J.N., 1981. Satellite estimation of the surface energy balance, moisture availability and thermal inertia. J. Appl. Meteorol., 20: 67-87.

Clapp, R.B. and Hornberger, M.G., 1978. Empirical equations for some soil hydraulic properties. Water Resourc. Res., 14(4): 601-604.

Cosby, B.J., Hornberger, M.G., Clapp, R.B. and Ginn, T.R., 1984. A statistical exploration of the relationships of soil moisture characteristics to the physical properties of soils. Water Resourc. Res., 20(6): $682-690$. 
Deardorff, J.W., 1978. Efficient prediction of ground surface temperature and moisture with inclusion of a layer of vegetation. J. Geophys. Res., 83(4): 1889-1903.

Kneizys, F.X. and co-workers, 1983. Atmospheric transmittance/radiance: computer code Lowtran6. Air Force Systems Command, USAF, AFGL-TR-83-0817.

Kuittinen, R. and Sucksdorff, Y., 1987. Inventory of river basin characteristics in Finnish conditions using satellite imagery. Aqua Fenn., 17(2): 97-114.

Ottlé, C., Vidal-Madjar, D. and Girard, G., 1989. Remote sensing applications to hydrological modelling. J. Hydrol., 105: 369-384.

Phulpin, T., Jullien, J.P. and Lasselin, D., 1989. AVHRR data processing to study the surface canopies in temperate regions. First results of HAPEX-MOBILHY. Int. J. Remote Sensing, 10 (4-5): 869-884.

Soarès, J.V., Bernard, R., Taconet, O., Vidal-Madjar, D. and Weill, A., 1988. Estimation of bare soil evaporation from airborne measurements. J. Hydrol., 99: 281 296.

Solantie, R., 1988. The albedo in Finland on the basis of observations on aircraft. Meteorol. Publ. No. 12, Finnish Meteorological Institute.

Taconet, O., Bernard, R. and Vidal-Madjar, D., 1986. Evapotranspiration over an agricultural region using a surface flux/temperature model based on NOAA-AVHRR data. J. Climate Appl. Meteorol., 25(3): 284-307. 